\title{
The Internet as the Present-Day Agora of Information and Knowledge
}

\section{Introduction}

Co-operation between people and organizations is always based on a two-way or multi-way flow of information. Information is constantly augmented, in terms of both quantity and quality. New technologies create practically unlimited possibilities of information generation, processing, storage, search, and perception. When co-operating with each other, we become the participants of the information market, since often co-operation is based on mutual exchange and the provision of specific information. That is important to the extent that information is a specific wealth and even a commodity on the information and innovation markets [1].

\section{Information as a Specific Kind of Goods in the Information Society}

The term "information society" used in this text means a "society which possesses not only developed means of information processing and communication, but also information processing constitutes the grounds for creating the national income and providing the sources of income for the majority of the society" [8, p. 43].

New information phenomena in the 21st century are the following:

- globalization of information processes and systems;

- international/global information exchange;

- development of cross-national information structures;

- necessity of information unification and standardization;

- qualitative changes of the information functions, processes and systems;

- modern information technologies (new mass media, electronic mass and global communication media);

\footnotetext{
* The Jagiellonian University, Institute of Informaction and Library Science, Krakow, Poland
} 
- polarization of the information society caused e.g. by the diversification of access to information (information gap, information exclusion);

- information consumption (information as a consumer commodity; commodity);

- information commercialisation;

- information economy and management;

- technical progress is based on information;

- consumer information production (information as commodity);

- development of the information sector;

- integration of information structures on a global scale (including international standards and globalization);

- globalization of infrastructure information systems.

Complexity and multi-aspectuality of information makes us assign a number of properties to information. Here are some of them:

- Information can be experienced although it is not possessed. Example: Mr. Jan Kowalski buys a Berlin guidebook, although he has never visited Germany. He acquires a certain object of information which will not become information for him until he follows the guidebook's instructions and sees the city.

- Information can be copied and transported in space and time.

- Information can be easily transmitted with telecommunication techniques.

- When copying and transmitting, information is neither used or lost; in opposition to material goods, information can be shared without loss.

- An act of information consumption does not destroy information that can be used many times and by many people. That feature of information is well illustrated by Bernard Shaw's story about apples and ideas: "If we have two apples and we share them with somebody else, we are left with only one apple; if we have two ideas and we share them, we are left with two ideas."

- The information production cost is much higher than the reproduction cost (that concerns in particular information in digital forms). Example: a film whose production costs 4 million euros can be copied to a DVD for several euros.

- Information can either reduce or generate uncertainty. Sometimes, the people who are better informed in some area can be uncertain of their knowledge in respect to those less informed.

- Information is an indivisible commodity. The problem of indivisibility is usually associated with the fact that information is transmitted in large portions. Example: when Mr. Jan Nowak wants to see only advertisements in his newspaper, he must buy the whole newspaper.

- For each user, the same information can mean something else. That results from subjective consideration of information by the users. 
- Information is non-linear. Even a small piece of information can bring about considerable consequences, while a large quantity of information can turn out to be useless.

- Information can be subjected to deformation or forgery either as a result of conscious actions of men or accidental events.

- The use of information can be simultaneous. The same information can be used by many people (organizations) concurrently and in many places at the same time.

- From an economic viewpoint, information can be recognized as a production factor just like other factors, e.g. labour or capital.

- Information can be treated as one of the economic categories [6, 7, pp. 19-23].

\section{Information Market in the $21^{\text {st }}$ Century}

By information markets we usually understand the markets on which one can acquire needed information from specialized suppliers, as well as the markets on which one can buy the information transmission service, e.g. ads in newspapers from specialized suppliers. Information markets are the derivatives of the new entities which offer information and knowledge for sale, gaining profit from the sale of information products and services.

The market (including information market) is assigned the following functions: contact making function, ineffective object elimination function, competition stimulation function, exchange function, gaining new qualifications function.

Information markets entail the processes of information production, exchange and consumption. Józef Oleński proposed that information markets should be explained by the following categories: demand for information, supply of information, information price and the factors which influence the information demand, supply and price, i.e. the cost, substitution and complementariness of information [9].

That requires taking into account the nature of information and of information processes and systems. The nature of the information market is determined by perceiving information as a commodity, product, service, consumer goods, production factor, product or an economic resource.

Wherever we have commodities, we have money. And that creates problems associated with the proper selection and management of information [2, 3]. Here, information ethics enters between the market participants. The information market operates in the conditions of incomplete and asymmetrical information and, consequently, errors often occur.

Information becomes a commodity when it is turned into an object of a market transaction. Information can be an object of a transaction as information in the form of an article (product), information service, access (right of access) to information resources. 
When knowledge is an object of a transaction, we are talking about knowledge markets. The following are mentioned as specific features of knowledge markets in the literature on the subject: the role of the suppliers' reputation and the necessity to create standards.

The characteristic features of the knowledge markets include the following:

- incomplete information about available knowledge,

- asymmetry of knowledge,

- local aspect of knowledge,

- prejudices about obtaining knowledge from unknown sources [9].

Those features can become reasons of pathologies occurring on such markets in the following: occurrence/development of artificial shortage of knowledge, occurrence barriers of knowledge exchange, and an unwillingness to share knowledge.

\section{Relation between Information Value and Information Price}

Is there dependence between information value and its market evaluation in the conditions of the internet, which is a specific information market, within the information society? We find that the relationship between information value and information price involves the following:

- On the one hand, the useful value of an information is perceived subjectively by the information user, while information is determined on the basis of such qualitative features as currency, truthfulness, completeness, accuracy and reliability.

- On the other hand, there is exchange value of information, or the price established on the basis of estimation that is affected by many factors being specific for the information market, such as complete information asymmetry, the "cat in a bag" syndrome, demand for information, and supply of information.

The juxtaposition of those two areas and their comparison allows us to think that information unpredictability, complexity, and subjectivity play important roles. We also find that the information value and its usability depend on the information user and the circumstance in which information is used.

Information has power whose effects can significantly influence the lives of both individuals and societies. It is interesting that the power does not depend on the quantity of information, but rather on the useful value of information.

Bohdan Stefanowicz described the power of information as follows: "It is not any kind of energy which influences man in a physical sense, but rather the factor which influences man's attitude, the types of his actions, and the decisions made by him through his mind. Owing to information entailed in the form of words (or 
presented in a different form), one man enters the mind of another man and transmits specific contents to him. Consequently, the image of the world developed by the person we are talking to is shaped in our minds to a certain extent, or the other person is suggesting his views to us. No surgery can enter one's mind as information can: surgery can change the brain's structure, which may not affect one's thinking processes, criteria or reality evaluation, preferred values or attitudes" [13].

Everyone should remember the power of information because that power determines the direction of human development. And that power also shapes the image of the present-day and future society, called the information society.

To determine the information value precisely, we should make reference to two classical conceptions of value, originating from the theory of economy that is exchange-value and use-value. In the considerations relating to the information value, the aspect of the exchange-value is applicable when information is a object of exchange, and thus it is a market commodity, with a specific price. The use-value is demonstrated by the information's ability to satisfy human needs. That value changes depending on who, when, in what situation, and for what purpose uses such information. The perception of use-value is justified in the situation, in which information is the main factor influencing decision-making processes.

\section{Internet: Information Market with Specific Features}

A traditional information market with the nature of a system becomes a network. The introduction of the internet accelerates many procedures, but extensive administration and bureaucracy causes delays. Possibly those are critical moments of a system after which only a better situation can be expected.

The information market is the market expanded by information. Therefore, it is not only a commodity market, but also a vanity fair. Here, we should talk about the market of ideas, life styles, fashions, religions etc. There is no single market, and the commodity market is not the only market. Here, purchase and sale transactions are not always associated with an autonomous unit product. What sells best are dreams and media, tourist, and lottery businesses know it perfectly well.

In the conditions of present-day information technologies, the following are characteristic features of the information market:

- flexibility, ease of individualization and personalization of information products;

- globalization, consisting in the fact that information generators and users operate on the multi-national or global markets;

- global standardization of information products;

- assumptions of regulatory functions, which used to belong to the domain of particular countries, by international organizations of political or economic nature [12]. 
According to Peter F. Drucker, the most important task facing management at the beginning of the 21st century is to ensure productivity increase among the knowledge workers, analogously to the 50-time increase of effectiveness of industrial workers in the 20th century.

The author also specified six main factors which influence the effectiveness of knowledge workers:

- The effectiveness of knowledge workers depends on accurate definition of the workers' tasks.

- The interested person is responsible for the level of effectiveness of the knowledge workers.

- Innovations are part of knowledge workers' responsibilities.

- Work based on knowledge requires constant personal development and improvement, as well as continuous training.

- The effectiveness of knowledge workers is not based on quantitative indicators. Qualitative indicators are equally essential if not the most important.

- When intending to increase the effectiveness of the knowledge workers, the organization must perceive that worker group in the categories of assets not costs [5].

\section{Information Market in Daniel Bell's Theory}

The present situation in Poland is similar to that projected in the 1960's and 1970 's by Daniel Bell, whose conceptions were discarded and replaced by other ones in the USA. We are bringing back his conception here without always realizing that, and failing to notice certain threats caused by that conception's implementation in the USA. That is why the conception has been presented here at least generally.

The main source of success under Bell's theory was the promotion of a new class, the class of information professionals, entailing intellectuals, university lecturers, managers, clerks, teachers and journalists, who are opinion-making elites. We should point out that it was a conception of fast growth based on the development of information science and technologies. Bell announced the triumph of science, computerization and rational management predicting that they would be decisive for the occurrence of a new post-industrial world.

In a post-industrial society, strategic resources would include knowledge and information that would play similar roles as work and capital in an industrial society. The added value of work was replaced by the added value of knowledge.

Bell assumed that, in the present-day world, the largest social changes would be caused by technical innovations. He predicted the dependence of present-day societies on knowledge, while information exchange and processing would become the foundation of all activities. Changes would be enforced by the development of telecommunication, mass computerization and information commercialisation. According to 
Bell, the most important activity of a post-industrial society would be information production. Bell proposed further economisation of social life, and he wanted to expand the market by adding information. He emphasized the economic dimension of information. Bell did not comment on the contradiction between the public nature of knowledge and its market value. In fact, there is a limit of the commercialisation of science, and, once it is breached, the development of science can be stopped. Contrary to Bell's statements, science and knowledge are not commodities as any other.

In Bell's theory, knowledge generation should replace commodity production. In other words, knowledge should be produced in an industrial manner. The ascent of a new class of information professionals, mentioned before, would be a consequence of the occurrence of the information society. The most prestigious figures of the information society would be scholars and engineers of knowledge. Bell proposed concentration and centralization of knowledge production. Treating academic education as commodity, he questioned the prestige of scholars as independent experts. Academic education became part of consumer offerings. That model undoubtedly leads to the fragmentation of knowledge. The science and knowledge markets become subjected to the ideology of progress. Bell proposed information industrialization which consisted in the production of information and knowledge for profit. The best suited for sale is information bereaved on any context and subdivided to portions [11]. Bell based his conception on a wrong assumption that information $=$ knowledge $=$ progress, which is not the case. Knowledge was supposed to be the basic commodity of the new era, while the information society would be based on the consumption of knowledge. Consequently, it would be necessary to divide knowledge into fragments which would be offered for sale in the form of stand-alone products. The reduction of information to a commodity, or something one can sell, is really a tremendous reduction. The information market in the economy based on knowledge production is involved in trading in the articles whose value (price) is hard to estimate, being autonomous, hard to identify and not subject to wear. The new social formation would be based on commercial information exchange. Universities would become factories that manufacture graduates [4].

\section{Some Experiences in the Development of the Information Markets in the Internet}

One notices contrasts when one looks from the outside. Now, some issuess will be presented from the informatological viewpoint rather. No effective systemic solutions exist in Poland. I mean macro-scale solutions. Solutions are rather temporary. Free style dominates (e.g. in respect of the university salaries, which are isolated from salaries in general). In science, similarly to other fields, what counts is the result, not the style. However, lack of synchronization (or reforms) can lead to the collapse of the system and its death or destruction. 
We notice valuable things in others, but we fail to notice them in us. We often know what people do across the Atlantic, and we have no idea what our colleagues do in the other room. We often take over ideas from others dropping our own valuable achievements which we should share with others. Lack of information is often subjected to manipulation. Confusing quality with quantity: quantity is transformed into quality, e.g. calculations of the so-called minimum personnel in universities: 2 masters of arts $=1$ doctor, 2 doctors $=1$ doctor of science (doktor habilitowany), 2 doctor of science (doktor habilitowany) $=1$ professor (which is nonsense!). The Polish educated class and the scholars' ethos have been destroyed by comparing their effectiveness to the effectiveness of blue-collar workers. The ties between reforms and their implementation have been broken. Reforms become the goals in themselves, turning them into inhuman solutions and directed against people. The average general level of education in primary, secondary, and tertiary schools that is available and mandatory for everyone has been considerably lowered after 1989. Today, we expect fast and immediate effects of actions. Time is money. Fiscalism is dominating now. Everything is expressed in money terms.

Since the time when information became valuable, everyone is running fast on the information highway. Information is the key to success. Universities have become in a sense the storage houses for those who would otherwise be unemployed. The society is undereducated. Commercialisation of science in Poland is a step forward, and two steps backward. The whole health care and education systems have been built on the wrong foundations, the same foundations as applied to production and industrial businesses, disregarding any differences.

\section{Conclusion}

The literature on the information value reveals the complexity and multi-aspectual nature of information, which causes difficulties with information value estimation. The scientific information market should be non-profit to some extent and the information market cannot be fully commercialised. In information and knowledge society, the increase of the volume of information and the number and scale of information intensify and accelerate the processes of ousting better information, which must be more expensive, by worse information, which is much cheaper for the stakeholders. In terms of growing information gaps under absolute information asymmetry, the stakeholders minimise their costs without awareness, that they accept poor quality information, which should rather be rejected [10, p. 30].

\section{References}

[1] Babik W.: Ekologia informacji. Wydawnictwo Uniwersytetu Jagiellońskiego, Kraków 2014. 
[2] Babik W.: Information Management in the Computer Communicated Society. [in:] $7^{\text {th }}$ International Seminar "Scientific and Technical Information in Central and Eastern Europe" Zakopane, October 26-28, 1998, OPI, Warszawa 1998, pp. 5-9.

[3] Babik W.: Sustainable Development of Information Society: Towards a Knowledge Management. [in:] 12 ${ }^{\text {th }}$ International Seminar "Scientific and Technical Information in Central and Eastern Europe" Zakopane, 21-24 May 2004, OPI, Warszawa 2004, 7 p. [CD-ROM].

[4] Dobrowolski Z.: Koncepcja społeczeństwa informacyjnego Daniela Bella. [in:] Sosińska-Kalata B., Przastek-Samokowa M. (red.), Od informacji naukowej do technologii społeczeństwa informacyjnego, Wydawnictwo Stowarzyszenia Bibliotekarzy Polskich 2005, Warszawa, pp. 87-105.

[5] Drucker P.F.: Zarzadzanie XXI wieku - wyzwania. New Media, 2010.

[6] Dziuba D.: Gospodarki nasycone informacja i wiedza. Podstawy ekonomiki sektora informacyjnego. Uniwersytet Warszawski, Warszawa 2000.

[7] Dziuba, D.: Metody ekonomiki sektora informacyjnego. Difin, Warszawa 2007.

[8] Goban-Klas T., Sienkiewicz P.: Społeczeństwo informacyjne: szanse, zagrożenia, wyzwania. Wydawnictwo Fundacji Postępu Telekomunikacji, Kraków 1999.

[9] Oleński J.: Społeczeństwo informacyjne i gospodarka oparta na wiedzy w świetle ekonomiki informacji. [in:] Pietruch-Reizes D., Babik W. (red.), Ustugi-aplikacje - treści w gospodarce opartej na wiedzy, Warszawa 2004, pp. 27-47.

[10] Oleński J.: Fundamentalne prawo jakości informacji w spoteczeństwie informacyjnym. [in:] Pietruch-Reizes D., Babik W. (red.), Kierunki i priorytety rozwoju informacji naukowej w kontekście budowania społeczeństwa wiedzy, Katowice 2006, pp. 19-34.

[11] Postman N.: Technopoly: The Surrender of Culture to Technology. Vintage Books, New York 1993.

[12] Shapiro C., Varian H.R.: Potegga informacji: Strategiczny przewodnik po gospodarce sieciowej. Helion, Gliwice 2007.

[13] Stefanowicz B.: Rola informacji. E-mentor, nr 5 (22), 2007, [on-line] http:// www.e-mentor.edu.pl/artykul/index/ numer/22/id /480 [access: 21.04.2016]. 